\title{
Assessment of the emotions that block Ecuadorian students from speaking English in class: Case Los Ríos Province
}

\section{Evaluación de las emociones que impiden que estudiantes ecuatorianos hablen inglés en clase: Caso Provincia de Los Ríos}

\author{
Jardel Coutinho dos Santos ${ }^{1}$ (D), Vanessa Veiga de Souza ${ }^{2}$ (D), Mayra Carolina Vélez-Ruiz ${ }^{3}$ (D) \\ ${ }^{1}$ Maestrando en Pedagogía de los Idiomas Nacionales y Extranjeros Mención Enseñanza de Inglés, Universidad Casa \\ Grande, Guayaquil, Ecuador. \\ 2 Maestranda en Lingüística Aplicada, Universidade Federal de Viçosa, Viçosa, Brasil. \\ 3 Doctora en Entomología, Facultad de Ciencias Agrarias, Universidad Técnica Estatal de Quevedo, Quevedo, Ecuador. \\ Autor para correspondencia: santos.coutinho@casagrande.edu.ec \\ Fecha de recepción: 3 de marzo de 2020 - Fecha de aceptación: 15 de abril de 2020
}

\begin{abstract}
This study aimed to define the emotions that block Ecuadorian students from speaking English in the classroom. The population within the research consisted of 138 participants, 80 from elementary school and 58 from high school, aged between 11 and 18 years. Information was obtained through classroom observations, questionnaires, interviews, and visual narratives. The results revealed that different emotions hinder students from speaking English in class, such as the fear of making a mistake, $30.80 \%$; fear of being judged by others, $21.88 \%$; shyness, $18.30 \%$; lack of confidence, $12.50 \%$; and anxiety, $2.68 \%$. Pearson's correlation tests revealed that there is an influence of gender with respect to the type of emotion experienced, female students expressed greater susceptibility to negative emotions compared to male students. Findings suggest that Ecuadorian teachers should be more aware of their students' emotions in order to find the possible approaches that may result in an improvement in their English language. The authors recommend carrying out more studies on the connection between emotions and speaking, or emotions and any other skills.
\end{abstract}

Keywords: Emotions, Ecuador, speaking, English, visual narrative, Pearson correlation.

\section{RESUMEN}

Este estudio tuvo como objetivo definir las emociones que impiden que los estudiantes ecuatorianos hablen inglés en la sala de clase. La investigación consistió en 138 participantes, 80 estudiantes de educación primaria y 58 de educación secundaria, con edades comprendidas entre 11 y 18 años. Los datos se obtuvieron a través de observaciones en el aula, cuestionarios, entrevistas y narraciones visuales. Los resultados revelaron que diferentes emociones impiden que los estudiantes hablen inglés en clase, entre ellas se encuentra: el miedo a equivocarse, $30.80 \%$; miedo a ser juzgado por otros, $21.88 \%$; timidez, $18.30 \%$; falta de confianza, $12.50 \%$; y ansiedad, 2.68\%. La prueba de correlación de Pearson reveló que existe influencia del género con respecto al tipo de emociones experimentadas por los estudiantes, de tal manera que, las estudiantes de sexo femenino expresaron mayor susceptibilidad a emociones negativas comparada con los estudiantes del sexo masculino. Los resultados sugieren que los maestros ecuatorianos deberían considerar las emociones de sus alumnos para encontrar posibles enfoques que permitan la mejora en el aprendizaje del idioma inglés. Los autores recomiendan realizar más estudios sobre la conexión entre las emociones y la producción oral, así como, las emociones y cualquier otra destreza.

Palabras clave: Emociones, Ecuador, producción oral, inglés, narrativa visual, correlación de Pearson.

\section{INTRODUCTION}

English undoubtedly became the world's lingua franca, the great majority of technological, scientific, academic, and social information is written in English. In this way, speaking more than one language is essential in order to interact and communicate in today's globalized world (National Curriculum Guidelines, 2014, p.5). For this reason, speaking is considered one of the most important skills of many researchers in Applied Linguistics (Candido-Ribeiro, 2008; Santos \& Barcelos, 2018) due to its level of importance, and complexity.

Speaking has a high level of importance because "most students often evaluate their success in language learning as well as the effectiveness of their English course based on how much they feel they have improved in their speaking proficiency" (Juhana, 2012, p.100). In other 
words, when asked if someone knows a foreign language, people usually think if they know how to speak that language, and they forget to mention the other language skills (listening, reading, and writing). Similarly, it has a high level of complexity. Mota, Bergsleithner, \& Weissheimer (2014) said that, among all human skills, speaking is considered the most complex due to the emotional factors as shyness, fear, motivation, self-esteem that surround communication. Santos \& Barcelos (2018) found that the reasons some Brazilian students were not able to improve their English speaking in a university context were connected with the fear of making mistakes, being judged by others, and shyness. This suggests the significant role that emotions play in the classroom and the learning of a foreign language. Some researches on this topic have shown how this skill is connected with social emotions (shyness, fears, anxiety, and low selfesteem).

In this way, this research builds on a previous study conducted by Juhana (2012), who addressed the psychological factors that hinder students from speaking English in a senior high school in South Tangerang, Banten, Indonesia. Our research interest is based on the following two factors: the first one is about the lack of researches regarding the Ecuadorian students' emotions, and the second one is the importance of teachers getting to know their students in order to improve their classes and make them more effective learning. To this end, this work investigates the emotions that are present in the English classes at three schools in Ecuador, and its relationship with the speak capacity of the participants. The specified objectives were: a) to characterize the emotions existing in the class; b) to verify whether students report problems in oral production due to these emotions; and c) to verify the correlation between emotions and sociobiographical variables (age and level of education). The article is divided into five parts. In addition to the introduction, in the second part, we briefly discussed the Ecuadorian context followed by a literature review. Then, we presented the methodology, the context, the participants, the data collection instruments and the analysis procedures. In the fourth part, we discussed the results and finally, we presented our considerations and implications of the research.

\section{THE ECUADORIAN CONTEXT}

English became the official foreign language taught in all the national territory of Ecuador (Avila, 2010) such as schools, technological institutes, and universities. In 1992, the Ministry of Education and Culture (MEC) and the British Council signed an agreement to improve the level of English of the country. This agreement is known as CRADLE (Curriculum Reform Aimed at the Development of the Learning of English) (see Ministerio de Educación y Cultura, 1997a \& 1997b, and UNESCO, 2004). This accord was considered essential to improve the teaching-learning process of the English language in the country's educational system (Auquilla \& Fernandez, 2017 , p.54). The project was based on the creation of a series of six books called Our World Through English. The series of materials (texts, listening activities, exams)

${ }^{1}$ Elementary School showed to the students the different realities of the country through the English language. It is estimated that these materials were used by approximately 1,200,000 students and their teachers in the school years from 1993-1994 to 1998-1999 (MinEduc, 2009). Unfortunate, this approach did not yield the expected results and a number of students did not reach the required level of English when they started the university (Calle et al., 2012).

Consequently, the Ministry of Education proposed a new methodology for teaching English based on the communicative-functional approach for the English curriculum for the eighth, ninth, and tenth year of Educación General Básica (EGB) ${ }^{1}$, and first, second, and the third year of Bachillerato $^{2}$. The approach is characterized by the following two main features: a) focus on real-world contexts, and b) relationship of language forms (grammar, vocabulary, and pronunciation) and function, and use (see National Curriculum Guidelines). This project aimed to improve the language skills of English teachers as well as their teaching practice and standardize English teaching (Auquilla \& Fernandez, 2017, p.56). It was expected that students could reach the communicative competences such as A1 at the end of the general basic education course, A2 at the end of the first year of the baccalaureate, and finally, B1 at the end of the third year of the baccalaureate" (León, 2018, p.1) according to the CEFR (Common European Framework of Reference). However, despite all the processes implemented by the government to improve the level of English in the country, Ecuador is the country ranked lowest in Latin America regarding English proficiency, and it is in number 81 out of 100 on the Mundial ranking (Cronquist \& Fiszbein, 2017).

\section{LITERATURE REVIEW}

\subsection{Speaking}

Nakhalah (2016) defines speaking as "the delivery of language through the mouth. To speak, we create sounds using many parts of our body, including the lungs, vocal tract, vocal cords, tongue, teeth, and lips" (p.99). It is considered one of the four foundational skills of language learning, such as listening, writing, reading and speaking. Ur (1991) said regarding the importance of the four skills "that speaking seems intuitively the most important: people who know a language are referred to 'speakers' of that language $[\ldots]$ (p.120)." Since students often assess their success in learning by their speech proficiency, recently high importance to speaking is given to a learner, what led to the fact that the ability to speak became a predominant objective in studying English as a Foreign Language (EFL) or English as a Second Language (ESL) (Consolo, 2006; Menezes, 2007; Hernández, 2010; Nakhalah, 2016, Santos \& Barcelos, 2018).

However, practicing, and developing speaking is not that easy, and it is not surprisingly that many students face problems in having to use a foreign language, like English, in real communication situations. This, in some way, may be associated with the lack of time to plan the speech since it happens spontaneously, and in real-time (Thornbury, 2006, p.208). Besides, some psychological factors influence students' oral production within the classroom

\footnotetext{
${ }^{2}$ High School
} 
(Rabab'ah, 2003, Cameron, 2001, Ur, 1996) such as those cited by Juhana (2012) in her study, in which she says that of the five psychological factors, fear of making mistakes is what most affects students (37\%), while shyness is the second $(26 \%)$, followed by anxiety (18\%), lack of confidence $(13 \%)$, and lack of motivation $(6 \%)$.

\subsection{Shyness}

Shyness is a topic that has been in vogue in Applied Linguistics lately especially in what comes to the development of speaking during classes (Zimbardo, 1977; Doyon, 2000; Axia, 2003; Candido-Ribeiro, 2008; Bashosh, Abbas, Rasteger, \& Marzban, 2013; Mohammadian, 2013; Santos \& Barcelos, 2018) because its influence on people's learning. Zimbardo $(1977)^{3}$ was one of the pioneers in the field of shyness. He made some researches on subjective experiences of shy people, links between shyness and self-processes, behavioral responses to shyness-arousing stimuli, and the consequences of shyness. All of these researches led him to a conclusion: "no single definition is adequate because shyness means different things to different people. It is a complete condition that has a whole range of effects - from mind discomfort to unreasonable fear of people to extreme neurosis" (p.13). In other words, shyness is a difficult term to define because it varies from person to person, but what is important to affirm, it can harm people's way of learning. Shyness is a type of emotion that some students suffer from when they are asked to speak in the classroom. People are born shy and the environment in which they encounter themselves helps them to develop this condition. Many factors can flourish shyness into students, such as: a) fear of making mistakes; b) fear of being judged by others; and c) lack of confidence.

\subsection{Fear of making mistakes}

Speaking English in class evokes many emotions. Anxiety, for instance, is one of the feelings that come to light when the students are communicating orally, and is according to some studies (Jackson, 2002; Liu, 2007; Savaşçi, 2014) linked to factors like fear of making mistakes, lack of confidence and among others.

The fear of making mistakes is one of the causes of anxiety and the absence or lack of speaking in class. In his studies Savaşçi (2014) found that students hate to make mistakes. Other studies stated that students are afraid of being despised or laughed at. They are worried about these aspects and because of this, they do not feel comfortable speaking in front of others. The grammatical rules also have an important role in the students' speaking. Because of the rules they feel afraid of making mistakes and check them every time (Ariyanti, 2016). One characteristic of the feeling is that the students "are afraid of making mistakes so whenever they feel that they have made a mistake in speaking, they directly repeat what they said" (Ariyanti, 2016, p.84). Sometimes, the learner does not even try or prefer not to speak because of the fear.

Shyness also has a place in what comes to the feeling discussed here. When the student is so shy, he decides not

\footnotetext{
${ }^{3}$ Philip G. Zimbardo is an internationally recognized scholar, educator, and researcher. He won numerous awards, and honors in each of these fields. He has been a professor at Stanford University, with more than 300 publications, since 1968 . He was recently president of the American Psychological Association
}

to participate. In summary, there are many psychological factors related to the students' feelings that has an impact on the students' performance when trying to speak in English classes.

\subsection{Fear of being judged}

Speaking English in the classroom, as mentioned in the article, has some factors which are related to emotions and feelings. The fear of being judged is one of them and can be about the other student, the teacher or himself. The fear, in this situation, is about the moment of speaking in class during the English classes. Also, as mentioned by Zhiping \& Paramasivam (2013), the fear at the moment of performance using the studied language, is "a phenomenon known as (foreign or second) language anxiety which can hinder performance and achievement" (Zhiping \& Paramasivam, 2013, p.1).

Shumin (1997) said that when speaking in front of others, people try to be cautious about what they say and about the errors. For her, the learners also fear to lose their faces while speaking English. According to this author, "the sensitivity of adult learners of making mistakes, or fear of losing face", has been the explanation for their inability to speak English without hesitation" (Shumin, 1997, p.206). Students who have this emotion are afraid of speaking in class because of some reasons: fear of being judged by others, fear of losing the face, fear of making mistakes and others. The fear of being judged is one emotion that is anticipated by the person. The learner thinks that the colleagues or the teachers will judge them while they speak so he/she anticipates this event and fears it. The fear can also bring together other emotions.

\subsection{Lack of confidence}

Confidence has been studied by authors because of its importance when it comes to teaching and learning a foreign language (Boonkit, 2010; Haidara, 2016; Melouah, 2013). This aspect is related to the effective factors in the acquisition of a language and the lack of confidence is considered one of the barriers in the process of learning. According to Melouah (2013), some methodologies and approaches help to reduce the levels of anxiety, improve their self-esteem and confidence.

Some of the factors regarding the lack of confidence are related to speaking English in class. Emotional factors appear in speaking and trying to communicate in the foreign language they are learning and are for instance the causes for anxiety (Melouah, 2013). Speaking English confidently is one of the questions of researchers and teachers (Boonkit, 2010) and is one of the problems faced while speaking (Haidara, 2016). The lack of confidence is a psychological factor that harms the performance of the students and has been a reluctance from speaking English (Haidara, 2016). The feeling of hesitance created by the lack of confidence can be related to many reasons and has to be studied in order to know the causal factors and how to remedy them.

and creator of a shyness clinic to study and deepen further on this subject. Among the many published books, for this research, we used the "Shyness: What it is, What to do about it." The book can be downloaded for free from the following website: https://bok.cc/book/3032655/66dc96. 


\subsection{Gender differences in emotions}

All humans experience some kind of emotions during their lives, and some of those emotions can or cannot coincide with someone's emotion (Bower, 1992). Some researchers tried to ascertain the correlation between emotions and gender (Allen \& Haccoun 1976; Allen \& Hamsher 1974; Block, 1983). Brody (1985) concludes that women report themselves as being sadder, scared, and emotionally expressive than men. Izard (1991) said that infants differ the frequency in which they express their emotions according to their gender. Some authors determined some differences in the way both gender act toward society. O'Barr \& Bowman (1980) found out that during conversations men interrupt women more than women interrupt men. Fishman (1978) discovered that men tend to do less "conversational work" than women. Herring (1994) states that it is possible to distinguish whether the writer of the message is a man or a woman because both have different writing styles. Goldshmidt \& Welter (2000) declared that Israeli women are more likely than Israeli men to express emotions in various conversational contexts. An explanation they made was because "boys play in larger, hierarchically structured groups, whereas girls group themselves more loosely in clusters of best friends". (Goldshmidt \& Welter, 2000, p.120). In this way, our emotions play an important effect on our lives whereas our lives are guided by our needs, motives, and concerns (Bower 1992).

\section{METHODOLOGY}

\subsection{Sample population}

This study was undertaken at three private schools in Ecuador located in the Los Ríos province. The research consisted of 138 participants, 80 from elementary school and 58 from high school, aged between 11 and 18 years old. Among the participants, 70 were female $(50.7 \%)$ and 68 were male $(49.3 \%)$ (Table 1$)$.

\subsection{Type of research}

The data collection consisted of observations, questionnaires, visual narratives, and interviews. Observations were made to find out the authors' hypothesis about the lack of students' speaking participation in the English class. The open-ended questionnaire was chosen because it allows the participants greater freedom in the answers (Santos \& Barcelos, 2018). The questionnaire contained nine questions, three open questions, and six closed questions, and it was divided into 2 parts. The first was focused on students' identification: name; age, gender; English study time; and the second focused on the psychological factors (Juhana, 2012; Nakhalah, 2016; Santos \& Barcelos, 2018). It was sent to each participant via google doc, and they had a deadline of one weak to answer. Each participant was asked to draw themselves (Kalaja, Paiva, \& Barcelos, 2008, Aragão, 2008) showing how they see them speaking English in the class. The interview was carried out for further clarification of some points in the participants' visual narrative or questionnaire, and took place with 10 students within a time lapse of 10-15 minutes.

The data analysis, based on Holliday (2005), consisted of the following steps: a) reading of all the responses to the questionnaires in order to search for significant units, and later grouping them in similar themes; b) analysis of the interviews, also identifying the significant units and verifying the other units, and placing them in similar categories; c) analysis of the visual narratives with the reading of the participants' written interpretation of the drawing; and d) recurrent readings of all instruments to verify the categories that appeared in the analysis. Also, the Pearson correlation test was conducted to check the correlation between emotions and sociobiographical variables (gender and level of education). From this data analysis, the most recurrent categories were related to emotions such as fear, shyness, lack of confidence and anxiety and their relationship with their oral production, themes that we will discuss in the next section.

\section{RESULTS AND DISCUSSION}

The research has shown, notwithstanding the English learners provided different opinions, that most of the students indeed have negative emotions that block them when they have to speak in class. Figure 1 depicts the percent distribution of the students' emotions when they speak English in the classroom.

Table 1. Demographic profile of the participants.

\begin{tabular}{|c|c|c|c|c|c|}
\hline & \multirow{2}{*}{ Age } & \multicolumn{3}{|c|}{ Years of studying English } & \multirow{2}{*}{ Total } \\
\hline & & $1-3$ years & 4-6 years & More than 6 years & \\
\hline \multirow{5}{*}{ 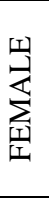 } & $11-12$ & 5 & 8 & 15 & 28 \\
\hline & $13-14$ & 1 & 8 & 17 & 26 \\
\hline & $15-16$ & 1 & 1 & 6 & 8 \\
\hline & $17-18$ & 1 & 3 & 4 & 8 \\
\hline & Total & 8 & 20 & 42 & 70 \\
\hline \multirow{5}{*}{ 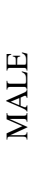 } & $11-12$ & 8 & 3 & 11 & 22 \\
\hline & $13-14$ & 2 & 5 & 15 & 22 \\
\hline & $15-16$ & 3 & 5 & 6 & 14 \\
\hline & $17-18$ & 4 & 2 & 4 & 10 \\
\hline & Total & 25 & 35 & 78 & 138 \\
\hline
\end{tabular}




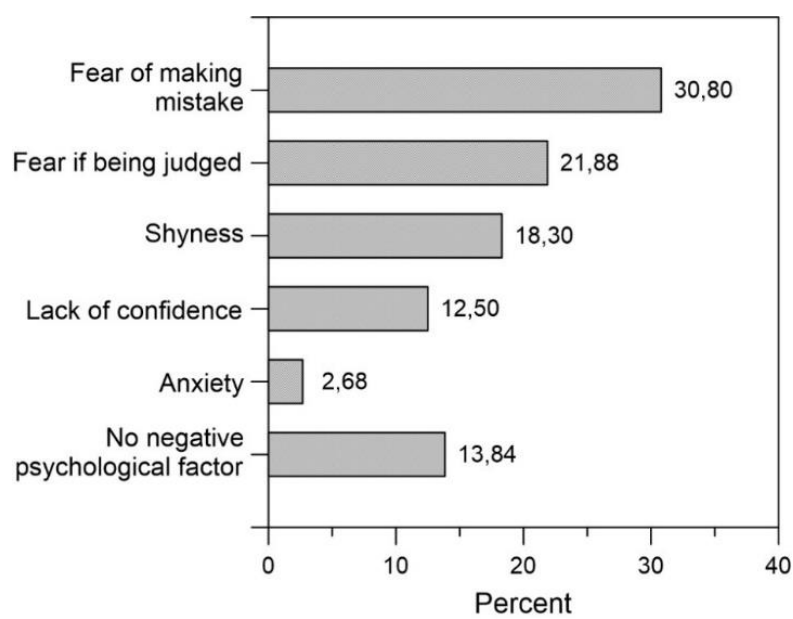

Figure 1. Distribution of the participants psychological factors when speaking English in class.

Of the 138 participants, 69 quoted that fear of making mistakes is the most common psychological factor, corresponding to $30.80 \%$; the second factor is fear of being judged by others, respectively 49 answers equivalent to $21.88 \%$; followed by shyness with 41 answers representing $18.30 \%$; lack of confidence with 28 answers or $12.50 \%$; and finally anxiety with 6 answers or $2.68 \%$. Likewise, 31 students, corresponding to $13.84 \%$, answered that they do not feel any negative psychological factor when they practice speaking in the class. The participants could choose more than one answer if necessary. A more detailed discussion of the information picked up from the students' perspective in terms of the causes of the emotions that block them to speak in the classroom is given, followed by an overview of the physical factors the students experience when speaking English.

\subsection{Fear}

The moment of speaking in front of a group can be related to the problem of fearing it. When it comes to fear, this feeling is associated with anxiety and can be a problem when the learners have to cope with this during the class while all the others are facing the person at the same time. Fear, as used by Jones (2004) in Tinjacá \& Contreras (2008), is like a phenomenon, language anxiety, which come up when the person is "provoked to speak in the second or the foreign language in public, with the risk of social embarrassment (p.10)". In the research presented in this article, some of the students presented two kinds of fear that hinder their participations in class: fear of making mistakes and fear of being judged.

\section{Fear of making mistakes}

Feeling insecure while doing something new can be considered a common feeling. Similarly, the students who are learning and trying to speak English in the class face this situation. For this reason, the fear of making mistakes arises and can block or suppress some of them. For the participants of the research, speaking English in class is groundbreaking and challenging. About all the factors mentioned by the learners in the questionnaire, fear of making mistakes is the major one.

Some students reported in the interview about what they feel in the moment of speaking. According to L1, she does not know how to explain precisely what she feels, it is like a mix of emotions.

I feel ashamed or afraid of making mistakes because the English I know is very basic and I should know its pronunciation and meaning correctly, and in English, many words have a different order and usually the teacher tells us to think in English and not literally translate the words of Spanish into English. (L1, Interview)

Another aspect of the student's speech is the inner feeling of self-charging. It is observed when she talks about what she should know and do correctly, which contributes to the fear of mistakes. This is also present in the speech of another participant, who feels afraid of making mistakes too. He reports:

Sometimes I'm afraid to make mistakes because people are expecting the best of me so if I make a mistake people will laugh at me or be disappointed at me. (L2, Questionnaire)

and mentions that, like in the other case, he is charged. The difference is that it is caused by another person, not by himself, and he thinks that if he makes a mistake, he will cause laughing and disappoint his classmates because of the mistake.

\section{Fear of being judged}

The fear as a major category presented in this study involves the fear of being judged. This feeling can also bring together many different aspects of emotions. The learners in the classroom can have the fear of being judged, what might cause the emergency of other related feelings. Some students reported that they feel this before or at the moment of speaking English. Besides, they have different feelings related to judgment. Some of the students feel bad like: "I feel bad when someone judges me." (L3, Interview), and this feeling can cause a fear of talking for the next time. Another example of feeling is when the students are afraid of not saying things right like they were supposed to do and afraid of the colleagues making fun.

I am afraid of being judged by others: I fear that when I am speaking and not saying the words well, my classmates make fun of me. (L4, Questionnaire) 
Because I am afraid of making mistakes or saying something wrong, my classmates would laugh at me and I don't like that. (L4, Interview)

The students' talk about the bad feelings they have when they are in the classroom and have to deal with different moments at the same time. The mixture of sensations leans the English learner to have a difficult moment, especially because he believes he will make mistakes or do something wrong. As a result, he feels afraid of being judged by others like learner 5, when she said: "I'm afraid of being judged by others." (L5, Interview).

\subsection{Shyness}

In this study, students told that they are shy and because of this, they have some difficulties to speak English. The first example is from an English learner, who is not only shy, but in addition she is afraid of the judgment of the others like she said:

I am very shy, and I am very afraid of people judging me when I am wrong, when I am talking or doing another activity. (L6, Interview)

The shyness blocks the person during the class because she thinks about the possibility of people judging her about her possible mistakes when she talks. Maybe if she was not shy, she could develop better. She portrays her feeling of speaking English in the visual narrative (Fig.2).

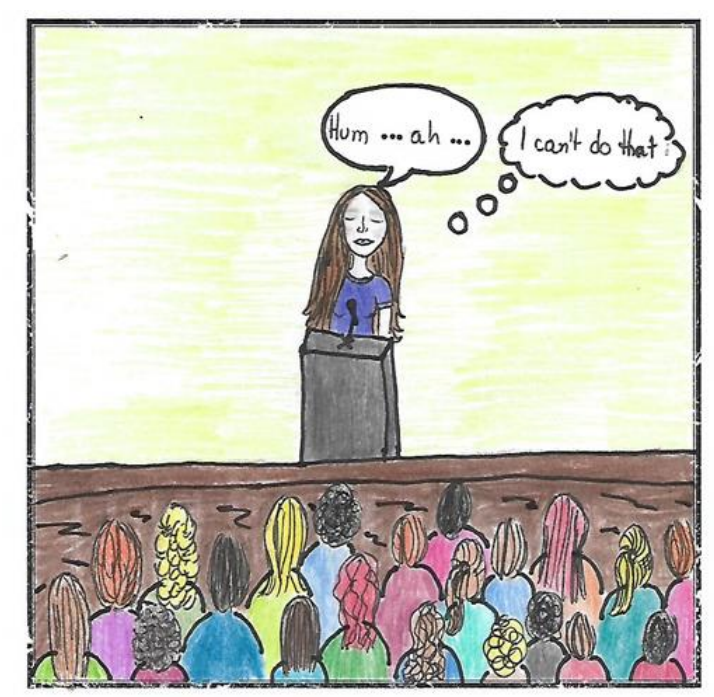

Figure 2. Visual narrative 1: Participant 6 speaking English in class.

Based on her drawing, we can say that this student feels the center of attention when she has to speak English in class. In her description of the visual narrative, she comments that all the time she has to speak, she feels she is lecturing to thousand people. She feels she cannot do it due to her shyness and fear of making mistake.

The other case is when the shyness makes the students not talk. The other participant shared during the interview that he does not speak in class because of the shyness:

I don't speak because I am very shy, and I feel

blocked. (L7, Interview)
As we can observe from the students' speech, shyness is an emotion that acts as an obstacle, which does not allow them to develop their skills in the language.

\subsection{Lack of confidence}

Confidence is one of the reasons that make people feel the courage to face or doing something. In this study, the students showed that the lack of confidence noxious them in the classroom. Mostly is lack of confidence connected to insecurity. One of the students narrated during the interview that apart from being shy she is insecure about the speaking moment:

\section{I have always been shy, and sometimes I feel insecure in the classroom at the time of speaking since most of the time I tend to care very little what they say about me I still feel insecure when speaking in public. (L8, Interview)}

The student does not have a problem with what the other students thought or say about her, but insecurity is something she feels when she has to speak in front of the others. Analyzing this, it is possible to say that the lack of confidence and insecurity are two feelings that might disturb learning.

\subsection{Anxiety}

According to the students in this study happens anxiety when they do not feel comfortable or confident about something of the learning process. The students linked the anxiety with what they think has not been developed yet. Some learners reported that this feeling is because of specific situations like the pronunciation, the meaning of the words, the use of the word, the speaking time, and others. Furthermore, facing certain kinds of situations seem to be difficult for some students. One of the English students of the class said that the pronunciation of the words makes him feel anxious:

Because I can't pronounce the words in English well. (L9, Interview)

At the same time, talking about words, another student told about her case of anxiety. She feels like this because sometimes she is not certain about the words, and because of this she feels insecure:

Because sometimes I forget the meaning of certain words and even how to use them and my fear is to say something meaningless or keep quiet. (L10, Questionnaire)

Analyzing the case, she feels anxious to speak in front of the whole class because she forgets some words, and how to use them. Even though it is a type of situation that does not occur only with this person, it is common to happen with anyone, and the way she feels in class is characterized in her visual narrative. It is possible to see that one of her arms is in her back holding the other one, and her eyes are looking down. Also, during the interview when she was requested to explain her visual narrative she said "during the English class, I look down not to be called by the teacher to answer any questions"; I am always anxious about having to say something and say it incorrect ( $L 10$, Interview). These are clear signs of an anxious person (Fig. 3). 


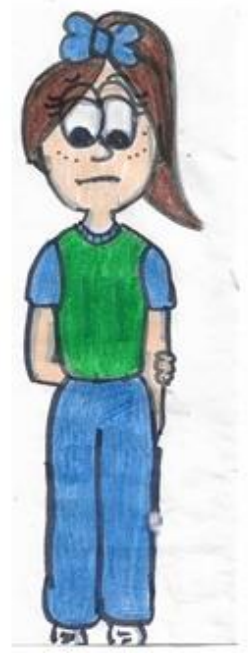

Figure 3. Visual narrative 2: Participant 10 speaking English in class.

Another example of anxiety in the moment of speaking is about one learner that has a problem with confusing himself, he does not want to face this situation and prefers to be quiet in situations that are not in the way he wanted to be. When he gets confused or does not want to be the reason for the students' laugh, he stops practicing.

When I have to speak English in front of the rest of the people around me, I am anxious about confusing myself. I don't like to seem a fool, or people laugh on me, that's why I often prefer to keep quiet than to continue practicing, however, I have to do it. (L11, Interview)

Based on the analysis of all comments made by the students, it is believed that anxiety and all other feelings hinder considerably the EFL learning and practicing.

\subsection{Gender differences in emotions during speaking}

In order to check the correlation between gender and the psychological factors that appear during speaking English in the class, an analysis based on the Pearson correlation coefficient was conducted. The results show that there are some correlations between three variables (fear of making mistakes, fear of being judged and no negative psychological factor) and gender. Table 2 presents the correlation between male and female students and psychological factors.

Table 2 demonstrates that some psychological factors are related to gender. Fear of making mistakes and fear of being judged are more common to flourish in the female gender according to the Pearson correlation, while the male gender is more likely to have no negative psychological factors when required to speak in the classroom. Both emotions by female students are related to the presence of the other. Staske (1996) affirms the partner plays an important social influence on human emotions during the conversation. This might happen because "men are more likely than women to speak assertively, talk more in public (...), in the meantime, women are less likely than men to speak in public..." (Goldshmidt \& Welter 2000, p.117). Also, Chaplin \& Aldao (2013) postulated that women show more internalizing emotions, such as sadness, anxiety, and fear.

\subsection{Educational level differences in emotions during speaking}

The same type of analysis, Pearson's correlation coefficient, was conducted to see the correlation between educational level, middle school and high school, and psychological factors during speaking English in the class. However, the results indicate that there is no correlation between them (Table 3).

Donovan \& MacIntyre (2005) also compared educational levels and emotions. However, he compared junior high school French immersion students, high school students, and university students. He had the same results, no correlation between them.

\subsection{Physical reactions when speaking English}

Besides the psychological factors during the speaking time, learners also experience different physical reactions. The English learners, as revealed by the questionnaire, reported the following physical reactions they feel when they speak English in the classroom: a dry mouth, fatigue, fast heartbeat, heartburn, nervous, red face, sweating, and trembling (see Fig. 4).

Physical reactions are common in this kind of situation and are considered related to emotional effects. As mentioned by Wang \& Roopchund (2015), reactions like accelerating heart rate, and blushing were reported to be, the most common physical reactions, besides trembling hands becoming cold, and feeling hot. The physical response of the body is most probably connected to the emotional status of the body. Summarizing, the psychological and physical effects become part of the environment of the classroom because complicated feelings, beliefs, perceptions, and reactions emerge in the classroom environment when learning and using a foreign language (Wang \& Roopchund, 2015, p.5).

Table 2. Correlation of gender and psychological factors.

\begin{tabular}{lccccc}
\hline \multicolumn{1}{c}{ Psychological factor } & $\begin{array}{c}\text { Pearson } \\
\text { correlation }\end{array}$ & $\begin{array}{c}\text { Sig. } \\
\text { (two tailed) }\end{array}$ & Male & Female & Total \\
\hline Fear of making mistakes & $-0,208^{*}$ & 0,017 & 27 & 42 & 69 \\
Shyness & $-0,073$ & 0,398 & 18 & 24 & 42 \\
Anxiety & $-0,114$ & 0,185 & 5 & 1 & 6 \\
Lack of confidence & $-0,008$ & 0,929 & 14 & 14 & 28 \\
Lack of motivation & $-0,056$ & 0,515 & 7 & 32 & 50 \\
Fear of being judged & $-0,208^{*}$ & 0,015 & 18 & 5 & 23 \\
No negative psychological & $0,231^{* *}$ & 0,006 & 18 & & 5 \\
factor & & & & & 5 \\
\hline
\end{tabular}

$* \mathrm{p}<0.05, * * \mathrm{p}<0.01$ 
Table 3. Correlation of levels of education and psychological factors.

\begin{tabular}{lccccc}
\hline \multicolumn{1}{c}{ Psychological factor } & $\begin{array}{c}\text { Pearson } \\
\text { correlation }\end{array}$ & $\begin{array}{c}\text { Sig. } \\
\text { (two tailed) }\end{array}$ & Middle School & High School & Total \\
\hline Fear of making mistakes & $-0,031$ & 0,720 & 44 & 25 & 69 \\
Shyness & $-0,067$ & 0,436 & 26 & 16 & 42 \\
Anxiety & $-0,027$ & 0,750 & 3 & 3 & 6 \\
Lack of confidence & $-0,037$ & 0,664 & 18 & 10 & 28 \\
Lack of motivation & 0,055 & 0,525 & 11 & 3 & 14 \\
Fear of being judged & 0,011 & 0,901 & 33 & 17 & 50 \\
No negative psychological & $-0,028$ & 0,744 & 15 & 8 & 23 \\
factor & & &
\end{tabular}

$* \mathrm{p}<0.05, * * \mathrm{p}<0.01$



Figure 4. Distribution of participants physical reactions when speaking English in class.

Physical reactions are common in this kind of situation and are considered related to emotional effects. As mentioned by Wang \& Roopchund (2015), reactions like accelerating heart rate, and blushing were reported to be, the most common physical reactions, besides trembling hands becoming cold, and feeling hot. The physical response of the body is most probably connected to the emotional status of the body. Summarizing, the psychological and physical effects become part of the environment of the classroom because complicated feelings, beliefs, perceptions, and reactions emerge in the classroom environment when learning and using a foreign language (Wang \& Roopchund, 2015, p.5).

\section{CONCLUSIONS}

As clearly shown by the collected data, Ecuadorian students possess emotions such as fear, shyness, anxiety, and lack of confidence that block them in the English class, impeding them to practice the language. All of these emotions are related to the presence of classmates. Students are afraid of making mistakes and been mocked by their colleagues. Also, the type of gender led students to feel different emotions during class. Female participants were more susceptible to experience negative emotions that male participants in the class. The same did not happen regarding the educational level of the participants. Therefore, Ecuadorian teachers should try to create a friendly classroom environment free of judgments, and fear. Also, be aware of their students' well-being. As possible solutions, teachers can make different dynamics to discover the students' feelings, and how they feel speaking in front of everyone. Based on this can teachers create an environment to develop good emotions and stimulate the students to speak step by step each class. Another possible action is to force the students to talk within small groups instead of asking them to address the classroom. Doing so the students might feel more confident and comfortable. All of these actions are geared to improve students' self-confidence and inner motivation. The authors hope that the results of this study can help Ecuadorian teachers to identify some causes of students' resistance to participate in the English class. Finally, more research on this topic is suggested to improve Ecuadorian students' oral skills, whereas the country lacks this information as well as researcher on the reason why there is no difference between the educational levels

\section{ACKNOWLEDGEMENTS}

The authors like to express sincere gratitude to all participants who contributed to this research, and all the schools from the Los Ríos Province which allowed them to carry out the research. 


\section{REFERENCES}

Allen, J., \& Haccoun, D. (1976). Sex differences in emotionality: A multidimensional approach. Human Relations, 29(8), 711-722. https://doi.org/10.1177/001872677602900801

Allen, J., \& Hamsher, J. (1974). The development and validation of a test of emotional styles. Journal of Consulting and Clinical Psychology, 42(5), 663668. https://doi.org/ 10.1037/h0037046

Aragão, R. (2008). Emoções e pesquisa narrativa: transformando experiências de aprendizagem. Revista Brasileira de Lingüística Aplicada, 8(2), 295-320. https://doi.org/10.1590/S198463982008000200003

Ariyanti, A. (2016). Psychological factors affecting EFL students' speaking performance. ASIAN TEFL Journal of Language Teaching and Applied Linguistics, 1(1). 65-84. http://dx.doi.org/10.21462/asiantefl.v1i1.14

Auquilla, D, \& Fernández, R. (2017). La educación Ecuatoriana en inglés: Nivel de dominio y competencias lingüísticas de los estudiantes rurales. Revista Scientific, 2(6), 52-73. https://doi.org/10.29394/scientific.issn.25422987.2017.2.6.3.52-73

Avila, K. (2010). La instrucción guiada en la motivación, aprendizaje y dominio del idioma inglés como segunda lengua a través de las hojas de trabajo basadas en el método Kumon. Tesis de Postgrado, págs. 167. Quito, Ecuador: Universidad San Francisco de Quito. Retrieved from: http://repositorio.usfq.edu.ec/bitstream/23000/243/ 1/95138.pdf

Axia, G. (2003). Timidez: um dote precioso do patrimônio genético humano. Tradução de Silva Debetto Cabral. São Paulo: Paulinas/Loyola. Coleção para saber mais, v. 3.

Bashosh, S., Abbas, M., Rastegar, M., \& Marzban, A. (2013). The relationship between shyness, foreign language classroom anxiety, willingness to communicate, gender, and EFL proficiency. Theory and Practice in Language Studies, 3(11), 2098-2106.

Block, J. (1983). Differential premises arising from differential socialization of the sexes: Some conjecture. Child Development, 54(6), 1335-1354. https://doi.org/10.2307/1129799

Boonkit, K. (2010). Enhancing the development of speaking skills for non-native speakers of English. Procedia - Social and Behavioral Sciences, 2(2), 1305-1309. https://doi.org/10.1016/j.sbspro.2010.03.191

Bower, G. (1992). How emotions affect learning? Pp 3-31. In: Christianson, S.-A. (Ed.), The handbook of emotion and memory: Research and theory. Hillsdale, NJ: Lawrence Erlbaum Associates.

Brody, L. (1985). Gender differences in emotional development: A review of theories and research. Journal of Personality, 53(2), 10249.

Calle, M., Calle, S., Argudo, J., Moscoso, E., Smith, A., \& Cabrera, P. (2012). Los profesores de inglés y su práctica docente: Un estudio de caso de los colegios fiscales de la Ciudad de Cuenca, Ecuador. Maskana, 3(2), 1-17.

Cameron, L. (2001). Teaching language to young learners. Cambridge, UK: Cambridge University Press. https://doi.org/10.1017/CBO9780511733109

Candido-Ribeiro, D. (2008). Timidez na aprendizagem de uma língua estrangeira sob a ótica dos alunos. Monografia (Licenciatura em Letras -

Português/Inglês), Facultad de Letras, Universidad Federal de Viçosa, Viçosa, Brasil. p. 68.

Chaplin, T., \& Aldao, A. (2013). Gender differences in emotion expression in children: A meta-analytic review. Psychological Bulletin, 139(4), 735-765.

Consolo, D. A. (2006). Classroom oral interaction in foreign language lessons and implications for teacher development. Linguagem \& Ensino, 9(2),33-55.

Cronquist, K., \& Fiszbein, A. (2017). English language learning in Latin America. The Dialogues. p. 82. Retrieved from https://www.thedialogue.org/wpcontent/uploads/2017/09/English-LanguageLearning-in-Latin-America-Final-1.pdf

Donovan, L., \& MacIntyre, P. (2005). Age and sex differences in willingness to communicate, communication apprehension and self-perceived competence. Communication Research Reports, 21(4), 420-427. https://doi.org/10.1080/08824090409360006

Doyon, P. (2000). Shyness in the Japanese EFL class. Why it is a problem, What it is, What causes it, and What to do about it. Tokyo, Japan: Kyoto JALT, The Language Teacher. p. 7.

Fishman, P. (1978). Interaction: The work women do. Social Problems, 25(4), 397-406. https://doi.org/10.2307/800492

Goldshmidt, O., \& Weller, L. (2000), Talking emotions: Gender differences in a variety of conversational contexts. Symbolic Interaction, 23(2): 117-134. https://doi.org/10.1525/si.2000.23.2.117

Haidara, Y. (2016). Psychological factor affecting English speaking performance for the English learners in Indonesia. Universal Journal of Educational Research, 4(7), 1501-1505. https://doi:org/10.13189/ujer.2016.040701

Hernández, T. A. (2010), Promoting speaking proficiency through motivation and interaction: The study abroad and classroom learning contexts. Foreign Language Annals, 43(4), 650-670.

Herring, S. (1994). Gender differences in computermediated communication: Bringing familiar baggage to the new frontier. Paper presented at the annual meeting of the American Library Association, Miami, June 27.

Holliday, A. (2005). Doing and writing qualitative research. London, UK: SAGE Publications Ltd., p. 216.

Izard, C. (1991). The psychology of emotions. New York: Plenum Press.

Jackson, J. (2002). Reticence in second language case discussions: anxiety and aspirations. System, 30(1), 65-84. 
Juhana, J. (2012). Psychological factors that hinder students from speaking in English class: A case study in a senior high school in South Tangerang, Banten, Indonesia. Journal of Education and Practice, 3(12), 100-110, 2012. Retrieved from www.iiste.org/Journals/index.php/JEP/article/view File/2887/2913

Kalaja, P., Paiva, V. M. O., \& Barcelos, A. M. F. (2008). Narrativising learning and teaching EFL: The beginnings in narratives of learning and teaching EFL. London, UK: Palgrave/Macmillan, p. 256.

León, M. (2018). Factors that affect the English language teaching-learning process in Ecuadorian Public High Schools. Tesis de Licenciado en Ciencias de la Educación - Inglés, UTPL. Quito. p. 68.

Liu, M. (2007). Anxiety in oral English classrooms: A case study in China. Indonesian JELT, 3(1), 119137.

Melouah, A. (2013). Foreign language anxiety in EFL speaking classrooms: A case study of first-year LMD students of English at Saad Dahlab University of Blida, Algeria. Arab World English Journal, 4(1), 64-76.

Menezes, V. (2007). As habilidades orais nas narrativas de aprendizagem de inglês. Trabalhos em Linguística Aplicada, 46(2), 165-179. https://doi.org/10.1590/S010318132007000200003

Ministerio de Educación del Ecuador. (2009). El proyecto CRADLE: Informe final. Quito, Ecuador: MinEduc, págs. 40.

Ministerio de Educación del Ecuador. (2012). National curriculum specifications: English as a foreign language. Quito, Ecuador: MinEduc, págs. 34.

Ministerio de Educación del Ecuador. (2016). Acuerdo nro. MINEDUC-ME-2016-00020-A. Quito, Ecuador: MinEduc, págs. 7.

Ministerio Educación y Cultura. (1997a). Modelo de Educación Intercultural Bilingüe. Quito: Ministerio de Educación y Cultura.

Ministerio Educación y Cultura. (1997b). Filosofía, Fundamentación y Lineamientos para los Seis Años de Estudio de Inglés en la Educación Media y Especificaciones del Programa Oficial. National Curriculum Administration. Foreign Languages Division. Quito: Ministry of Education and Culture.

Mohammadian, T. (2013). The effect of shyness on Iranian EFL learners' language learning motivation and willingness to communicate. Theory and Practice in Language Studies, 3(11), 2036-2045. htpps://doi.org/10.4304/tpls.3.11.2036-2045

Mota, M., Bergsleithner, J., \& Weissheimer, J. (2014). Situando a pesquisa sobre produção oral em LE. Em: Bergsleithner, J., Weissheimer, J., \& Mota, M. (Eds.), Produção oral em LE: Múltiplas perspectivas. São Paulo, Brasil: Pontas.
Nakhalah, Al. (2016). Problems and difficulties of speaking that encounter English language students at Al Quds Open University. International Journal of Humanities and Social Science Invention, 5(12), 96-101.

O’Barr, W., \& Bowman, A. (1980). Women's language or powerless language? Pp. 93-110. In: McConnell-Ginet, S., Borker, R. \& Furman, N. (Eds.). Women and Language in Literature and Society. New York: Praeger.

Rabab'ah, G. (2003). Communication problems facing Arab learners of English. Journal of Language and Learning, 3(1), 180-197.

Santos, J., \& Barcelos, A. (2018). Não sei de onde vem essa timidez, talvez um medo de parecer ridículo: Um estudo sobre a timidez e a produção oral de alunos de inglês. Revista Horizontes de Linguistica Aplicada, 17(2), 15-38. https://doi.org/10.26512/rhla.v17i2.22627

Savaşçi, M. (2014). Why are some students reluctant to use L2 in EFL speaking classes? An action research at tertiary level. Procedia - Social and Behavioral Sciences, 116, 2682-2686. https://doi.org/10.1016/j.sbspro.2014.01.635

Shumin, K. (1997). Factor to consider: Developing adult EFL students' speaking abilities. In: Richards, J. \& Renandya, W. (Eds). Methodology in language teaching: An anthology of current practice. Cambridge, UK: Cambridge University Press. p. 204-211.

Staske, S. (1996). Talking Feelings: The collaborative construction of emotion in talk between close relational partners. Symbolic Interaction, 19(2), 111-135. https://doi.org/10.1525/si.1996.19.2.111

Thornbury, S. (2006). An A-Z of ELT. Oxford, UK: Macmillan.

Tinjacá, R., \& Contreras, R. (2008). Overcoming fear of speaking in English through meaningful activities: A study with teenagers. Profile Issues in Teachers Professional Development, 9, 23-46.

Unesco. (2004). Informe nacional sobre el desarrollo de la educación. Disponible en www.ibe.unesco.org/international/ice47/english/nat reps/reports/ecuador.pdf

Ur, P. (1991). A course in language teaching: Practice and theory. Cambridge, UK: Cambridge University Press.

Wang, P., \& Roopchund, R. (2015). Chinese students' English-speaking anxiety in asking questions in the Msc Tesol classroom. International Journal of English Language Teaching, 2(2), 1-18.

Zhiping, D., \& Paramasivam, S. (2013). Anxiety of speaking English in class among international students in a Malaysian University. International Journal of Education and Research, 1(11), 1-16.

Zimbardo, P. (1977). Shyness - What it is, What to do about it. Massachusetts, USA: Addison Wesley Publishing Company. 